\title{
KONTAKTY SW. AUGUSTYNA Z PAPIESKIM RZYMEM
}

Przez "Rzym papieski" rozumiemy tu osobę kaźdorazowego biskupa rzymskiego or az jego najblizszych współpracowników. Ci ostatni to przede wszystkim ludzie z Kuril Rzymskiej oraz legaci papiescy, wysyłani w sprawach kościelnych do Afryki łacińskiej. Przyjęty w tytule termin nie zawiera więc w sobie przeciwstawienia wobec "lzymu cesarskiego", bo tego ostatniego w czasach śr. Augustyna praktycznie w naszym rozumieniu nie było. Cesarze zachodni dawno przestali już rezydować w rzymie: przebywali przeważnie w Mediolanie, a od roku 402/404 cesarz Honoriusz obrał solie za siedzibę Rawennę. "Kontakty św. Augustyna z papieskim Rzymem" to po prostu kościelna współpraca Biskupa lippony z kolejno po sobie następującyni papieżami i $1 \mathrm{ch}$ najbliższym otoczeniem.

Trzeba tu jednak od razu uświadomić sobie rzecz nieco zaskakującą. Siv. Augustyn jako kapĩan $i$ jako biskup nigdy nie by w Rzymie. Oznacza to, że przy swoich wszystkich możliwościach nie złożył on - jako duchowny - ani razu wizyty papieżowi. A przeciez obowiązki kapłana 1 biskupa pełnił w sumie niemal 40 lat, gdy równocześnie podróż statkiem z Hippony czy Kartaginy do Wiecznego Miasta trwała wtedy 3-4 dni.

W Rzymie jednak św. Augustyn kiedyś był. Zdarzyło się to po raz pierwszy jesienia $383 \mathrm{r}$, kiedy w poszukiwaniu lepszej pracy w zawodzie nauczycielskim opuścił Kartaginę• Osiadł wedy na pare niesięcy nad Tybrem. Po raz drugi $i$ już ostatni bawił w Inymie jako świezo pozyskany dla Kościoła neofita. Po otrzymaniu chrztu w Mediolanie z rąk św. Ambrożego wracał z matką 1 przyjaciółmi do ojczystej Mfryki. Smierć św. Moniki w Osti1 spowodowała najpierw oczywista przerwe w podróży, a następnie zmusiła św. Augustyna do zatrzymania się na dłuzej w Wiecznym Mieście. Cały ten drugi, dużo ważniejszy od pierwszego pobyt, trwał mniej więcej od listopada 387 do września $388 \mathrm{roku}^{1}$.

1 W każdym razie pod koniec $388 \mathrm{r}$. był św. Augustyn znowu 
Pobyt w Italil w latach 383-388 stanowił waściwie jedyná pozaafrykańska podróż św. Augustyna. Wiele napisano o przyczynach owej jego niechęci do podróżowania, wskazując przede wszystkim na nieperne zdrowie Biskupa Hippony. Skądinąd jednak wiadomo, że niestrudzenie brał udział w licznych synodach afrykańskich, zasiadał w ówczesnych kornisjach kościelnych, często podejmował publiczne dysputy z przeciwnikani, a już bez końca przemawiał podczas rozlicznych uroczystości kościelnych. To wszystko wymagało zdrowia. I chociaz wierzyny św. Augustynowi, kiedy przez całe życie uskarżał się na róźne doleg̀liwości ${ }^{2}$, to przecieź chcemy równieź wierzyć jego ucznlowi, biskupowi Possydiuszớ z Kalamy, który zapewniał, ze niemal do ostatniej chwili życia ten 76-letni starzec zacinował dobry wzrok, dobrze słyszał $i$ był w niezłej kondycji ogólnej ${ }^{3}$. Wydaje się zatem, że do uwarunkowań fizycznych należy koniecznie dodavać okoliczności zewnętrzne, jak na przykład to, ze episkopat afrykański jako całość zmlerzał do ograniczenia wyjazdów bisksupich na dwór cesarski do Rawenny, nie popierajac tym samyin zbyt częstych wędróweir biskupich do Rzymu. Sw. Augustyn byz zbyt prostolinijny, aby się do tego samemu nie stosować. Mogło to wypływać również ze względów najbardziej osobistych, które go powstrzymywały od wędróweik za morze - jak np. wspomnienie pożegnania ze św. Monikiz w ostii 4 . Będąc człowiekiem bardzo wraźliwym

w Kartaginie /por. G. Bardy, Swį̨ty Augustyn. Człowiek 1 dzieło, tłum. Z. Kobylańska, Warszawa 1955, 124; taik że J. Czuj, Żywot świętego Augustyna, Warszawa 1952, 91/.

2 Por. F. van der Meer, Saint Augustin pasteur d'ânes, $t .1$, Paris 1955, 41 i $363 \mathrm{n}$. /zestawienie chorób i niedomagán św. Augustyna/.

3 Possidius, Vita s. Augustini 31, PL 32, 64, POK 11, XCIII.

4 Por. Confessiones IX 11, 27, PL 32, 775, tłum. J. Czuj, POK 9, 219: gdzie dyspozycja umierajacej Moniki brzmi jak nienaruszalny testawent 1 wskazówka dla jej synów: "Złóżcie rzekła - to ciało gdziekolwiek; niech wam troska o nie nie sprawia kłopotu; o to was tylko prosze, abyście przed ołtarzen Pańskin o mnie paniz̨tali, gdziekolwiek będziecie"; tanże IX 11, 28, PL 32, 776, POK 9, 219-220: "Dla Boga nic nie jest dalérie i nie należy sie lękać, aby on przy końcu świata nie wiedział, skįd mie wskrzesić z martwych". 
mógł ze słów matki wyciaggnąć wnioski, dla nas już niezrozumiałe, by nie wracać więcej na ten grób.

iv tej sytuacji kontakty św. Augustyna z papieskim Rzymem będa się ograniczać do korespondencji z papicżami $i$ do spotkań osobistych z wysłannikami papieskimi - ale tylko na ziemi afrykańskiej. W sprawach korespondencji z Rzymem św. Augustyn bez oporu i chętnie posługiwał sie pośrednictwem przyjaciół 1 znajomych, którzy dla własnych powodów wędrowali do Italii. Takim niestrudzonym podróżnikiem "za morze" był np. uczeń św. Augustyna, a później jego współpracownik i serdeczny przyjaciel, biskup Tagasty, Alipiusz. Do Italii jeździli Possydiusz z Kalamy, Fortunatus z Sicca Veneria i wielu innych, którym sw. Augustyn pisemnie 1 ustnie powierzał swoje sprawy do przedłożenia $w$ papieskim Rzymie.

Pytajmy jednak do koŕca: czy św. Augustyn widział w swej młodości biskụa Rzymu, czy z nim rozmawiał, kiedy to dwukrotnie zatrzymywał się w Wiecznym Mieście? Odpowiedź negatywna nie jest taka oczywista, jakby się z pozoru mogło wydawać.

To prawda, że milczą na ten temat źródła. Jednakże znając zachowanie się św. Augustyna robec biskupa Mediolanu 1 biorąc pod uwage zwiçzłość opisu własnego chrztu, można zakładać, że już podczas pierwszego pobytu w kymie ten poszukujący 1 niespokojny, a przy' tyn nieco rozczarowany do manicheizmu młody człowiek, z czystej ciekavości brał udział w papieskich celebrach 1 pewnie słuchał czasea, jak przemawial sędziiry Damazy /366-384/. Trudno też sobie wyobrazić, aby podczas drugiego pobytu w Rymie świeźo ochrzczony, poruszony śmiercią matki 1 marzący o życiu mniszyin, św. Augustyn nie przepędzał nawet całych godzin w tamtejszych bazylikach i nie przyblizał sie tym bardziej do katedry Piotra. Nie powiedział nam jednak, czy tyle przynajmniej rozmaiviał z przychylnym życiu monastycznemli papieżem Syrycjuszem /381-399/, ile przed niewielu laty mówił ze św. Ambroz̀ym w Mediolanie.

Wydaje siq, że kontakt tego rodzaju musiaz laieć niejsce. Wiemy przecicź skądinad, ze św. Augustyn znal osobiście i by w przyjaźni z kapłanem Bonifacym, późniejszym papiezem. Nie jest wykluczone, że znał osobiście także takich późniejszych papieży jak Innocenty I /402-417/ i Celestyn I /422-432/5 Dzialalność 
biskupa Augustyna i jego pisma zdaja się wskazywać, że główno postacie Kurii Rzymskiej na przelomie IV i V w. były mu $\mathrm{f}$ jakimś stopniu osobiście znane. Poznał tych ludzi przynajmniej z widzenia chyba wtedy, gdy po śmierci matki zatrzymał się w Rzymie na okres kilku miesięcy. Ten rzymski czas należy na pewno zaliczyć do szczególnych darów, jakie Doktor Laski otrzymał w swym życiu z rąk opatrznośc1 ${ }^{6}$.

\section{KATOLICKI RODUVÓD ŚT. AUGUSTYYA}

Napisano o św. Augustynie, że jest on najpiękniejszą, najbardziej złożoną 1 najbardziej pociągającą osobowością W Kościele Zachodnim, a przy tym wielkim artystą starożytności chrześcijańskiej ${ }^{7}$ : Szczególna łaska Boża towarzyszyła mu od momentu przyjścia na śriat. Guy bowiem Afryka łaciniska IV w. rozdarta była boleśnie na dra niemal jednakowe obozy - -katolików 1 donatystów - on urodził się jednak w rodzinie katolickiej. Ojciec był wprawdzie "wiecznym katechumenem", ale $i$ on otrzymał $w$ "ivyznaniach" wiele ciepłych słów. Katolicka gorliwość matki wypezniała zreszta tamten brak w nadmiarze. W liście apostolskim "Augustinum Hipponensem", wydanym 28 sierpnia 1986 r., papież Jan Paweł II podkreślił, że nawrócenie św. Augustyna nie było zupełnie nowym odkryciem i przylgnięciem do Chrystusa, lecz raczej powrotem do początków wiary zaszczepionej mu w dzieciństwie. On właściwie nigdy nie odłączył się od Chrystusa, a tylko odszedł na pewien czas od Chrystusowego Kościoła ${ }^{8}$ Podobnie trzeba widzié jego chrzest jako świadowe nawiązanie do tego, co katolickie, a co posiadał w zaczątrach, gay był bardzo młody.

Warto ciąśnąć dalej ten wątek. Jego pobożna, ale prosta matka nie znała chyba uczonych wywodów św. Cypriana, kiedy czciła tego męczennika $i$ hiskupa, $j$ ak wszyscy wierzący Afrykanie

centeşo/; Epistolae 192 i 209, CSEL 57, 165-167 i 347-353 /Listy dugustyna do Celestyna/.

6 "ryznania" są jednym wielkim dziękczynienien św. Augus tyna za otrzymane łaski Boze.

7 Jest to charakterystyka pióra P. de Labriolle'a /Histoire de l'Eglise, ed. Fliche-liartin, Paris 1948, IV 52/.

8 Augustinum Hipponensem cp 1, zob. wyżej s. 
i modliła sie do Boga za jego przyczyna. Ale syn Moniki był dzieckien tradycji św. Cypriana. Dziedzictwo tej tradycji w dzledzinie eklezjologii było takie, że nie ma prawdziwego 1 tyın bardziej jednegro Kosicioła Chrystusowego - bez Piotra wcielonego w osobe biskupa Rzymu. Z drugiej strony dumni 1 dobrze zorganizowani Afrykanie powtarzali za sw. Cyprianem, ze nie ma Kościoła powszechnego bez silnych Kościołór lokalnych z ich odrębnościani dyscyplinarnymi 1 liturgicznymi ${ }^{9}$.

Kilkunastoletni Augustyn nie musiał słyszeć o św. Optacie, biskupie miasta Milewe w Numidil, ale pogląd owego pisarza kościelnego na temat papiestwa, wyrażony w dziele "De schismate donatistarum", napisanym ok. 370 r., był odbiciem powszechnej świadomośc1 katolików afrykańskich tamtego czasu. Idąc śladani \&w. Cypriana 1 rozwijając jego myśl bistup optat z Milewe przypominał to, co także donatyści dobrze powinni byli wiedzieć, ze mianowicie, Stolica Apostolska jest ośrodkiem jedności Kościoła powszechnego, a biskup rzymski zajmuje wyjaticowe miejsce w światowym episkopacie 10 .

W ogólnym klimacie takiego właśnie myślenia 1 wierzenia wzrastał sw. Augustyn. Na bieżąco, w swych latach dziecięcych 1 młodzieńczych mógł oczywiście o tym nawet dokładniej nie wiedzieć, ale w dalszej perspektywie ów klimat myślenia propapieskiego w domu św. Moniki musial zaowocować. A przeciez dochodziły jeszcze inne czynniki.

W porzadku faktycznego oddziaływania na myślenie św. Augustyna o papiestwie należy na pierwszym miejscu postawić św. Ambrożego. I to nie dlatego, by ci dwaj męzowie kiedykolwiek taki temat razem omawiali, lecz z powodu ogólnego zauroczenia, jakiemu uległ św. Augustyn w zetknięciu z pismaini, osobowością

9 Por. F. van der Meer, dz.cyt., t. 2, 26.

10 Por. Optatus, De schismate donatistarum II 2, CSEL 26, 36. Por. G. Haendler, Von Tertullian bis zu Ambrosius. Die Kirche im Abendland vom Ende des 2. bis zum Ende des 4. Jahrhunderts, Berlin 1978, 125; P. Batiffol, Le catholic1sme de Saint Augustin, Paris 1920, $100 \mathrm{nn}$. 
i działaniem Biskupa Mediolanu ${ }^{11}$. Ten, który tyle zaczerpnąz z dorobłcu św. Ambrożogo, nie mógł nie odnotorvać jego słarnego adagium: "Ubi Petrus, ibi Ecclesia"12. Nie mógł on równocześnie nie dostrzec 1 tej strony zagadnienia, że św. Ambroży mocno akcentował kolegialność w Kościele 1 realna współodpowiedzialność całego światowego episkopatu za losy chrześcijaństwa.

Do tego spadku po św. Cyprianie i św. Ambrożym doszły własne przemyślenia św. Augustyna na gruncie Pisma św. i codziennej rzeczywistości kościelnej. Sw. Augustyn długo szukał pewności intelektualnej i duchowej, ale w końcu zrozumiał, ze w dziedzinie wiary perność matematyczna jest do osiagnięcia niewozliwa. Trzeba bylo zaufać Pismu św. Ono rzeczywiście stało się reguła 1 normą działania św. Augustyna. Ale i za Pismo śv. musiał ktoś poręczyć, a następnie dawać jego poprawną wykładnię wobec faktu, iź często interpretowano je źle. Tym najwyżsym autorytetem poreczającym i wyjaśniającym Pismo św. był dla śiv. Augustyna Kościóz katolicki. Wiara woga i wiara w Kościół szły u niego w parze zgodnie z dewizą, że kto przyjmuje Boga za swego ojca, winien zarazem przyjąć Kościół jako swą matkę 13 .

11 Por.J. Czuj, Żyrot śri. Aựustyna, dz•cyt., 65.

12 Ambrosius, Explanatio super psalmum 40, 30, CSEL 64, 250. Por. Rops, Kościół pierwszych wieków, tłun. K. Ostrowska, Warszawa 1968, 585; L. Małunowiczówna, Ambroży, EK I 414 n.

13 Por. Sermo $92 / \mathrm{MaI} /$, PLS 2, 483: "Neque poterit quispiam propitium habere Deun patrem, qui Ecclesian contewpserit matrem"; Enarratio in psalmum 88 II 14, CCL 39, 1244, tłum. J. Sulowski, PSP 40, 161: "Uniłujny Pana Boga naszego, ukochajmy Jego Kościół. Pana jako ojca, jego jaḱo matke. Jego jairo Pana, Kościół jako służebnice Jego, ponieważ jesteśny synari Jego słuźebnicy. Hałżeństwo to jednak jednoczy wielka miłość. Nikt nie obraża jednego, a zjednuje sobie drugiego /.... Co powoże ci to, żeś nie obraził ojca, który mści się za zniewage matki? Na co ci sie przyda, że wyznajesz Pana, Bogu oddajesz cześć, głosjsz Go, Syna Jego uznajesz, wyznajesz, że siedzi po prawicy Ojca, a bluźnisz przeciw Jego Kościołorri? Czyż nie sprowadzajal cię na wiaściviz droge proykłaliy malżeństw ludzkich? Jeśli miałbyś jalijogoś patrona, któremu codzieiníe usługiwałbyś, którenu słuzac wycierałbyś progi, któređo codziennie

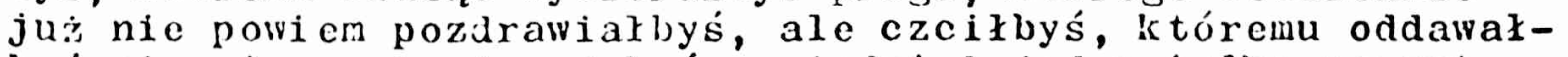
byś wiernie posługi, gdybyś powiedziat jeden tylko zarzut przeciwlio jeł̧o małżnce, czy wszedłbyś do jego domu? Zatem, najdrozsi, trzymajcie sie wszyscy jednonysinio Boga ojca 1 matki Kościoła": P. Batiffol, Cathedra Petri, Paris 1938, 19. 
Stopniowo dojrzewała w nim myśl o przemijaniu wszelkiej rzeczywistosci zienskiej - łacznie z organizmami państwowymi, nawet w wymiarze cesarstwa rzymskiego - i równocześnie niezmiennym trwaniu Kościoła. Ten Kościół, rozrzucony po całym okregu ziemi, mlał być na zarsze jednym ciałem Chrystusorym. To ciało mistyczne Chrystusa miało z kolei swój widzialny punkt odniesienia w papieskim Rzymie.

Tak się przedstawia w największyn skrócie katolicki rodowód św. Augustyna: Należy teraz zobaczyć, jak ta formacja katolicka zdała próbę życia w burzliwych dla APryki latach u schyłku IV w., a przede wszystkim na początku wieku V. Jak wyglądały kontakty św. Augustyna z lizymem papieskim w ci agu 40 lat jego kapłaństwa i biskupstwa?

\section{TRUDNOSCI WEJSCIA W OBOWIAZZKI KAP LANSKIE}

Na dobra sprawę mógł się czuć św. Augustyn niezbyt w porządku wobec nzymu już od pierwszych dni swego kapłaństwa, które w dość szczególnych okolicznościach przyjął w 391 roku. Stary biskup Faleriusz liczył na jego pomoc w posłudze słowa. Kapłan Augustyn podjął ową posługe nie tylkow dawnym rozumieniu jako nauczyciel katechumenów - doctor audientium - lecz równieź jako kaznodzieja, przemawiajacy do ludu takize w obecności swego biskupa. Tak było na l'scilodzie - 1 o tym dobrze wiedzial wyrodzący się stantąd Waleriusz - ale na Zachodzie, a już na pewno w Afryce, było inaczej. Publicznie präemawiał tu biskup ${ }^{14}$. Augustyn poszedł dalej, bo nie odrzucił propozyoji, by na synodzie w Hipponie w 393 r. wygłosić główne przeriówienie do wielu obecnych tam biskupów.

14 Possidius, Vita S. Augustini 5, PL 32, 37. Sw. Ilieronim na temat tego obyczaju zachodniego wypowiadaz sie, jak zwykle, jednoznacznie. Por. Epistola 52, 7, PL 22, 534, tłum. J. Czuj /šw. Hieronim, Listy, Warszawa 1952/, I 339: "Wi niektórych Kościolach panuje bardzo niedobry zwyczaj, że kapłani milcza i w obecności biskupów nie głosza kazań, jairby biskupi zazdrościli in, albo nie raczyli ich słuchać. Apostoł Paweł mówi: 'I gdyby jednemu z siedzacych zostało coś objawione, pierwszy niech zamilknie. Możecie bowiem wszyscy po jednenu prorokować, aby wszystkich pouczyć i wszystkich pocieszyé. A sizy ducha proroczero sa w mocy 
Upomnienia z Rzynu za to oczywiście nie otrzymał. Wkrótce sam został biskupem i sprawa już go nie dotyczyła. Ale cieszy sie, kiedy przychouziły wiadomości, że prymas Afryki Aureliusz, także dopuszcza niektórych kapłanów do tego przywileju i obowią$z^{15}{ }^{15}$. Jednakże część biskupów afryixańskich ciągle miała zastrzeżenia ${ }^{16}$. Augustyn musiał przeżywać pewien niepokój jeszcze u schyłku życia, gdy dowiadywał si̊, że papież Celestyn wyraża wobec biskupów galijskich obawy co do przygotowania doktrynalnego kapłanów podejmujących ciężar kaznodziejs twa ${ }^{17}$.

Wynika z tego, że św. Augustyn od pierwszej chwili swego oficjalnego włączenia sie w życie własnego Kościoła lokalnego musiał jakoś godzić ze soba przynajmniej trzy czynniki: posunięcia episkopatu afrykańskiego, stanowisko Stolicy Apostolskiej oraz własne rozuwienie prawdy obiektywnej i dobra dusz. Źycie miało go nieraz stawiać wobec konieczności trudnego wyboru.

Taka trudność wynikła w zwiazzku ze święceniami biskupimi sw. Augustyna. Wszystico dokonało się w sposób dość niezwykły, a śr. Augustyn uległ żądaniom hippońskich katolików i ich starego biskupa Waleriusza. Dotychczasowy kapłan został koadiutorem z prawem następstira. od początku sam oświadczał, że zwyczaj tego zakazuje. Wytłunaczono inu jednak, że konsekrowanie nowego biskupa za życia jego poprzcdnika bywało juz w Afryce $i$ zdarzało sie "za morzew". Później stwierdził, że jednak złamany został ósmy konkreinie kanon Soboru Nicejskiego - zgromadzenia kościelnego tak drogiego dla Stolicy Apostolskiej - który polecał, aby w tym samym mieśc1e funkcje sprawował tylko jeden biskup ${ }^{18}$. Kiedy więc na 4 lata przed śmiercia prezentował ludowi kandydata na swogo następce w osobie kapłana Herakliusza, postanowił jednocześnie, aby nie udzielać mu sakry za swego życia ${ }^{19}$.

proroków. Bóg bowiem nie jest Bogien waśni lecz pokoju'/1 Kor $14,30-33 /$. Chwałą ojca jest syn madry'/P’rz 10,1 ; $15,20 /$. Niech sic cieszy biskup z oceny swojej, z tego, że takich wybrał Chrystusowi kapianów".

15 Por. Epistola 41,1, CSliL $34,81-32$.

16 Possidius, Vita S. Aurustini 5, PL 32, 37-38.

17 Por. Caelestinus, Epistola 21, 2, PL 50, 528. Por tajize

J. Gaudenet, L'Eglise dans l'Lmpire Romain/Ive-ve siecles/, Paris 1958,594

18 Por. Conciliorus occunenicorum decreta, Bologna 1973 $3^{3}, 10$; Possidius, Vita S. Augustini 8, PL 32, 39-40.

19 Por. Epistola $213,4-5$, tłuil. J. Czuj/Zywoi św. Au gustyna, 
Przyjęcie święceń bis'supich oznaczało dla św. Augustyna pełne wejście na oficjalną scenę Kościoła afrykańskiego, którego głównym probleneri by $¥$ wedy kryzys donatystyczny. Wyroki papieskie i cesarskie zapadły w tej sprawie juz dawno i przechylić szale ku jedności mogły teraz tylko wewnętrzne, prokatolickie siły w Kościele afrykańsisim. Przez cały nienal wiek IV Stolica Apostolska w takiej sytuacji prawie nie interweniowała w Afryce. W tym lokalnym Kościele umocnił się więc jeszcze bardziej dawny zmysł autonomii i wrażliwość na punkcie prawdziwych czy pozornych uprawnielí episkopatu afrykańskiego.

Sw. Augustyn od samego poczatku pamiętał jednak o pryncypiach. Nawiązał bardzo szybko do dawnych afrykińskich poglądów o papiestwie. W ułożonym przez siebie Psalmie "Contra partem Donati", który pochodzi z lat 393-396, wyłożona została nauka Optata $z$ bilewe o Kościele katolickim jako krzewie winnym. Ten, kto sie odłącza od jego korzeni, może jakiś czas żyć 1 ładnie wygladać - ale będa to tylko pozory życia. Lączność ze Stolica Piotra jest warunk1em jedności kościelnej. W kolejnym następowaniu po sobie biskupów rzymskich objawia się owa opoka, która łączy biskupa każdego czasu z Linusem, Piotrem $i$ wreszcie samym Chrystusem $^{20}$. Już jako biskup Hippony pisał na przełomie $397 / 398 \mathrm{r}$. z wielka rewerencja o Kościele nzymskim, "in qua semper apostolicae cathedrae'viguit principatus" 21.

Pragnienie zlikwidowania schizmy donatystycznoj dyktowało jechak episkopatowi afrykaískiemu, a z nim także św. Augustynowi, pewne posunięcia praktyczne, które nie zawsze zgadzały się z linia działania Stolicy Apostolskiej. Najgłośniejsza sprawa był tu problem tych duchownych, którzy chcieli wrócić do Kościoła

dz.cyt./, s. 213: "Nie chce przeto, aby ganić należało w synu moin to, co nagany goanyn było we mnie /... Będzie kapłanem, jak jest, biskupen będzie, kiedy Bóg zechce".

20 Psaluus contra parten Donati $226 \mathrm{nn}, \mathrm{CSEL} 51,13$. Por. W. Warschal1, Karthargo und Rom. Die Stellung der Nordafrikanischen Kirche zum Apostolischen Stuhl in $M 0 m$, Stuttgart $1971,47 \mathrm{nn}$.

21 Epistola 43, 7, CSLL 34, 90. 
katolickiego z zachowaniem sivoich stanowisk 1 Punkcji. W Afryce nie tyle myślano o jakiejś literalnej likwidacji donatyzmu, 110 raczej o pojednaniu obu stron - a taka koncepcja wymagała zarsze posunięć przynajıniej subtelnych.

Synod odbyty w IIpponie w 393 r. zadecydował, ze należy zatrzymać na stanowiskach takich biskupów, opuszczających szeregi donatyzau, którzy nigdy nie rebaptyzowali, a wracając obecnie prowadzili do Kościoła cała swoja trzode. Synod postanowiz także dopuszczać do kapłaústwa takich kandydatów, którzy - jako dzieci - ochrzczeni byli wśród donatystów 22 .

Hokóz tych postanowień zrodziły się wącpliwosci w Italii. Powyzsze rozstrzygnięcia zostały więc w 397 r. przesłane w formie zawiadomienia do papieza Syrycjusza /384-399/ i biskupa Mediolanu Symplicjana. Tego ostatniego św. Augustyn znał osobiście i uwieczniz w "Wyznaniach". Zarówno papiez jak i następca św. Aabrożego odrzucili decyzjc podjęte w Afryce. Ale episkopat afrykański nie myślał łatwo ustąpić. Papiez Anastazy /399-402/ w 401 r. potwierdziz negatywną decyzje Syrycjusza 23 . Afrykanio jednak pozostali przy swoim ze wzylędu na żywione przekonanie, że istnieje realna szansa zjednoczenia Kościoła i ciaggle chodzi o pożytek dusz. Postanowili stosować sie do zdania Rzymu w przypadku, gdy duchowny wracal bez swej trzody; wtedy nie był dopuszczany do pełnienia funkcji kapłańskich w Kościele katolickim. Kiedy jednak przyprowadzał ze soba cała ginine, pozostarał na stanowisku juz jako biskup katolicki. Tíyjaśnienie synodu, że nikt w Afryce nie zamierza godzić w uchwały podjęte w Italii, ma na sobie juz jakieś piętno tego formułowania myśli, które jest właścire św. Augustynowi $i$ jeszcze wiele razy dojdzie później do głosu 24 .

22 Por. Registri Ecclesiae Carthaginensis excerpta 57, CCL 149, 195; Breviarium IIPponense 37, CCL 149, 43-44.

23 Syrycjusz zmarl 26 listopada 399 r. 0 tej decyzji por. Registri Leclesiae Carthayrinensis excerpta 65-66, CCL 149, 198-199.

24 Tanize 68, CCL 149, 200: "Propter Lcclesiae pacem et utilitatem /.../ si hoc paci Leclesiae prodesse visun fuerit, in suis honoribus suscipiantur, sicut prioribus eiusder divisionis temporibus factum esso manifestun est; /.../ Non ut concilium, quod in translitarinis partibus de hac re factum est, dissolvatur, sed ut illud anant circa cos qui sic transire ad catholican volunt, ut nulla per eos unitatis catholicae compensalio procuretur. Pe: quos auten vel omi modo perfici vel adiuvari, lianifestis fraternaruri animarmm lucris, catholica unitas in loci: cuibus ceunt visa fuerit, non eis obsit quod 
Papiez Innocenty I nie podnosiz ze swej strony wspomnianej kwestii duchownych donatystycznych. Konferencja zjednoczeniowa katolików i donatystów z $411 \mathrm{r}$. w Kartaginie poszła w obranym uprzednio kierunku i umożliwiła byłym donatystom, wracającym do Jedności razen ze swyni viernymi, pełnienie Punkcji kapłaniskich na równi z katolikami ${ }^{25}$. Sw. Augustyn w tym punkcie mógł być odtįd spokojny.

\section{WALKA Z PELAGIANIZMEMI}

Omówione dotąd zagadnienia nie stworzyły dla św. Augustyna okazji do bardziej bezpośrednich kontaktóiv z papieskim Rzymem. Hierrał niepokoje sumienia lub razem $z$ innymi biskupani podejmował - na własny rachunek - rozwlązania, które mogły służyć perspektywicznemu dobru Koścıła lokalnego. Ciazgle jednak wobec Stolicy Apostolskiej pozostawał jakby w cieniu. Źycie miało to wszystko odmienić i spowodować, że Biskup Hippony pewnego dnia stanle w pierwszym szeregu tych, którzy - jak za najlepszych lat zwróca sie o ponoc do Stolicy Piotra. Stało się tak najpierw za sprawa pelagianizmu, który na początku $V$ w. rozpetał dugotrwałe spory na temat łaski Bożej i wolnej woli człowieka.

Dla przyby'łego z Rzymu Pelagiusza miał św. Augustyn duzo sympatii 1 podziwu. Był sławnym ascota, a taki typ ludzi zawsze mu imponował i pobudzał jego wyobraźnie. Szczęściem był Biskup Hippony wrażliwy nie tylko na zewnętrzne gesty, lecz także na sposób myślenia 1 wierność wobec starych zasad Kościoła. A tutaj trudności ujawniły się, gdy tylko przyjaciel Pelagiusza, Celestiusz, chciał zostać kạłanem 1 z tej okazji nieco dokładnlej określıł poglądy własne 1 swojego mistrza.

Synod biskupów afrykańskicín z $411 / 412$ r. odrzucił pelagiańskie stanowisko w kwestii łaski. Augustyn, zajęty konferencja

contra honores eorum, qualivis salus nulli interclusa sit, in transmarino concilio statutur est, id est ut ordinati in parte Donati, si ad catholican correcti transire voluerint, non suscipiantur in honoribus suis secundum transmarinum concilium, sed exceptis his, per quos catholicae unitatis consulitur". Por. F. van der Meer, dz.cyt., t. 1, 154-155. 
zjednoczeniowa katolików 1 donatystóv, nie wział w tym synodzio udziału, ale niemal natychmiast włączył sie do dyskusji popierając i uzasadniając szeroko na piśmie decyzje synodu. Episkopat afrykański nie widział jeszcze potrzeby angażowania w te sprawe Stolicy Apostolskiej, ale własne odwołanie - już z Efezu - posłał do Rzymu Celestiusz/który na ivschodzie osłągnazz jednak kapłaństwo/. Przyspieszenie biegu wypadków nastąpiło z chwilą, guy przyszła wiadomość z Palestyny, że synod w Diospolis uniewinnił pelagian. Kościół afrykański został znowu poderwany do działania. Odbyły się dwa równoległo synody: dla prowincji prokonsularnej i dla Numidii. Nastappiz jakby zaplanowany z góry podział ról. W Kartaginie obradowało ok. 70 biskupów pod przewodnictwer pryinasa Aureliusza. Sw. Augustyn tam nie pojechał, bo Hippona formalnie nalezała do Nimidil, ale wział za to udział w synodzie milevitańskim, który zgromadził ok. 60 biskupór .

Teraz nastał punkt zwrotny w całej sprawie. Oba synody afrykańsicio przesłały sie alita do rąk papiezà Innocentego. Biskupowi rzymskiemu przedstawiono powage sytuacji akcentując $\rho$ akt, że pelagianizm kwestionuje znaczenie modlitwy $i$ odrzuca chrzest dzieci. Biskupi prowincji prokonsularnej prosili o uroczyste potęplenie błęuów teologicznych na temat wolnej woli $i$ losu dzieci nie ochrzczonych. W całej sprawie odwoływali się bez reszty do powagi Stolicy Apostolskiej ${ }^{26}$.

Synod milewitariski zawarł w swym piśmie stwierdzenie, że autorytet biskupa rzyinskiego wypływa z Pisma św. 27 Za tym stanowiskien opowiadał się oczywiście św. Augustyn, a papiez znakomicie zrozumiał cała uyśl i odpowiadając na to pismo dobitnie nawizzał do osoby Piotra Apostoła 1 swojego urzqdu apostolskiego ${ }^{28}$.

26 Por. Augustinus, Epistola 175, 2, CSEL 44, 655: "Ut statutis nostrae mediocritatis etian Apostolicae Sedis adhibeatur auctoritas, pro tuenda salute lultorum et quorumdan perversitate etian corrigenda"; tanize, 3, 658: "Naiore gratia de Sede Apostolica praedicas".

27 Terize, Lpi:jtolu 176, 5; CSLL 44, 668: "Auctoritati Sanctitatis tuae de sanctarum Scripturarum auctoritate deproliptae". Por. II. Jedin, Storia della Ciniesa. trad. italiana, t. 2. Milano $1977,282 \mathrm{n}$.

28 Por. Augustinus, Lpistola 182, 3, CSLL 44, 717-719; II. Rahner, Kościół i panstuo we wezesnyen cinzześcijuástivio, tłum. M. Padozycka, warsziwa 1936,132 n.; P. Batiffol, Le catholicisme, dz.cyt., $33 j \mathrm{j}$ n. 
Pięciu biskupów dołączyło do pism synodalnych własny list do papieża Innocentego ${ }^{29}$. List był napisany, jak się wydaje, od początku do końca ręką św. Augustyna ${ }^{30}$. Biskupl radzili wezwać Pelagiusza do Rzymu, aby tan zdał sprawe z tego, co głosi $1^{31}$. Na koniec tego oiszernego listu jego nadawcy usprawiedliwiali sie, że dalecy sa od pouczania papieża w tyin, co ma saglzić 1 czynić, ale bardzo in zalezy na papieskim wyroku ${ }^{32}$.

Papiez Innocenty uznał wyrok APrykańczyków za swój własny. Pisał w odpowiedzi do biskupów Numidi1 - czyli przede wszystkim do św. Augustyna - że zwrócenie się do papiesłịgo Rzymu w sprawach wiary oznacza pytanie saiego sív. Piotra, a to przynosi korzyść wszystkim Kościołom lokalnym na całym świecie ${ }^{33}$. Natomiast

29 List do Innocentego I skierowali: Aureliusz z Kartaginy, Alipiusz z Tagasty, Augustyn z Hippony, Ewodiusz z Uzalis 1 Possydiusz z Kalamy/por. Epis tola 177, CSEL 44, 669-688/. Jalk widać, była to wspólna reprezentacja kościelna prowincji prokonsularnej /2 biskupów/ i Nunidii /3 biskupów/.

30 Por. np. użycie pierwszej osoby liczny pojedynczej, cp. 12, CSEL 44, 680: "Puto autem".

31 Por. Epistola 177, 3, CSEL 44, 671-673. Innocenty nie widział jednak takiej konieczności /por. Epistola 181, 9, CSLL 44. $712-714$; 183, 2-4; CSEL 44, 725-727.

32 Epistola 177, 19, CSSL 44, 688: "Dabit sane nobis veniam suavitas mitissima cordis tui, quod prolixiorem epistolam fortassis, quain velles, tuae misimus Sanctitati. Non enim rivulum nostrum tuo largo fonti augendo refundimus; sed in hac non parva tentatione teinporis, unde nos liberet, cui dicimus: $\mathrm{Ne}$ nos inferas in tentationem, utrum etiam noster licet exiguus ex eodem, quo etiam tuus abundans, emanet capite fluentorum, hoc a te probari volubus tuisque rescriptis de communi participatione unius gratiae consolari".

33 Epistola 182, 2, CSEL 44, 717: "Praesertin quoties Pldei ratio ventilatur, arbitror oines fratres et coepiscopos nostros nonnisi ad Petrum, id est sui nominis et honoris auctoren referre debere, velut nunc rettulit vestra Dilectio, quod per totum mundum possit Ecclesiis omntbus in commune prodesse". Por. G. Bardy, dz.cyt., 326 n. 
biskupów z synodu kartagińskiego chwalił papiez za ich odwołanie się do następcy św. Piotra, gdyż oznacza to wierność wobec starej tradycji i rozumienie porządku w Kosciele ${ }^{34}$.

Biskupi afrykańscy z wdzięcznościa przyjęli zarówno tréśc jak $i$ ton rzysaskiej odpowiedzi. Do św. Paulina z Noli pisaz pózniej Augustyn, ze Stolica Apostolska odpori edziała Afrykanom tak, jak należło się tego po niej spodziewac ${ }^{35}$. Dla Biskupa Hippony dyskusja w gronio chrześcijan była w ten sposób zakończona.

Tynczasem 12 marca $417 \mathrm{r}$. zmarł Innocenty I. Po 6 dniach wakansu zasiadł na stolicy rzymsiriej Zozyn, do którego zgłosił się z osobistym odrołaniem Celestiusz. Z dalekiej Palestyny odwoływał się rówilez Pelagiusz, wsparty listem biskupa Jerozolimy. Od wszystisich pelagian słyszał Zozysa gorace zapewnienia o ich ortodoksji i gotowości poddania się sprariedliwym decyzjom papieskiego Rzymu.

Akcja ta przyniosła niespodziewany skutek. We wrześniu $417 \mathrm{r}$. Zozym uznał za szczere deklaracje Pelagiusza o jego prawowiernośc1. Wyrzucał tez biskupom z Afrylii ich łatwowiernośc wobec oskarżeí rzucanych na człowieka pośrięconego Bogu. W sprawie Celestiusza papiej dziwił sį pospiechowi 1 surowości postepowania episkopatu afrykańskiegro i zostawiał sprawę do ponownego rozpatrzenia ${ }^{36}$.

34 Epistola 181, 1, CSEL 44, 701-702: "In requirendis divinis rebus, quas omni cum sollicitudine decet a sacerdotibus, maximeque a vero iustoque et catholico tractari concilio, antiquae traditionis exempla servantes et ecclesiasticae memores disciplinae nostrae religionis vigorem non minus nunc in consulondo quam antea, cuin pronuntiaretis, vera ratione firmatis, qui ad nostrum referendum adprobastis esse ludiciun scientes, quid Apostolicae Sedi, cum omnes hoc loco positi ipsum sequi desideremus apostolum, debeatur, a quo ipse episcopatus et tota auctoritas nominis huius emersit".

35 Epistola 186, 2, CSEL 57, 47: "Scripsinus etian ad boatissialae memoriae Papam Innocentiun praeter conciliorum relationes litteras familiaros, ubi de insa causa aliquanto diutius egiaus. Ad omnia nobis ille rescripsit eo nodo, quo fas erat atque oportebat Apostolicae Sedis antistitem".

36 Por. Epistola Zostiai ad Apricanos episcopos, Hansi IV 350352 . 
IV rzeczywistości to papiez działał trochę pochopnie. Byz najpierw $\nabla$ trudnym położeniu, jako że rzymskiej/np. przyszły papiez Sykstus III/ pozostawały początkowo pod urokiem pelagian ${ }^{37}$. Poza tyn opowiadał sie za Celestiuszem moźny ród Anicjuszów 1 wiele innych szanowanych $\mathbf{w}$ Rymie osób ${ }^{38}$. Ale nade wszystko chcial Zozyn uratorać obu tych zdolnych przecioz ludzi oraz ich współpracownikow dla Kościoła. Nie mógł przy tym wiedzieć, że już wkrótce sam Celestiusz odmówi stawienia się na wezwanie papieza 1 będzie sie ratowal ucieczką z Italii.

Oświadczenia papieża Zozyma dotarły do Kartaginy dnia 2 listopada 417 r. Między Kościołem afrykańskim a Stolicą Apostolska zarysował się poważny konflikt. Co robił wtedy sw. Augustyn?

On cały czas podtrzymywał stanowisko episkopatu afrykańskiego. Wobec pelagian i ich sympatyków odwołał się jeszcze wo wrześniu $417 \mathrm{r}$. do oryginalnego rozumowania. Oto Stolica Apostolska ma racje, a jest to racja zawarta w stanowisku Innocentego I. Rozdrapywanie sprawy od nowa nie ma sensu, skoro aź dwa synody posłały listy do papieża Innocentego 1 - co waźniejsze Afryka otrzymała z Rzymu pozytyme odpowiedzi. W konkluzji kazania, wygłoszonego 23 września 417 r. w Kartaginie, padły słowa św. Augustyná o zakończonej w ten sposób sprawie: "Roma locuta - causa finita"39. Powyższe rozumowanie ujęto w forme aforyzmu, który idzie za św. Augustynein przez wieks. W swoim literalnym kontekście nie ma ta wypowiedź charakteru tak uroczystego, ale tak ujęty jej sens jest zupełnie poprawny i nie zmieniony.

37 Por. Augustinus, Epistola 194, 1, CSEL 57, 176: "Quod enim fatendum est caritati tuae, tristes eramus nimis, cum fama iactaret inimicis Christianac gratiae te favere!"

38 Por. W. Eborowicz, Wprowadzenie, w: Sw. Augustyn, Laska wiara przeznaczenic, Poznań $1971=$ POX $27,27$.

39 Sermo 131, 10, PL 38, 731: "Fratres mei, compatimini mecum. Ubi tales inveneritis, occultare nolite, non sit in vobis perversa misericordia: prorsus ubi tales inveneritis, occultare nolite. iledarguite contradicentes, et resistentes ad nos porducite. Jam enira de hac causa duo concilia missa sunt ad Sedem Apostolicam: inde etiam rescripta venerunt. Causa Pinita est: utinar. aliquando finiatur errorl Ergo ut advertant monemus, ut instruantur docenus, ut mutentur oremus"; por. Epistola 186, 2, CiEL 57,46-47; G. Bardy, dz.cyt., 328329 . 
W Rzymie papieskim koniczy się bowiem ostatecznie wszelka teologiczna dysirusja pomiędzy chrześcijanami.

Pomiędzy llzyıem 1 Afryka dokonywała sie teraz ustawiczna wymiana listów. Sw. Augustyn położył na szali cały swój - jakże już wtedy wielki - autorytet biskupi. W marcu 418 r. papież Zozym był wreszcie wolny od złudzeń i nanisał Afrykanom, ze omawiana sprawa jest dalej otwarta. Wiadomość te Afrykanio otrzymali 29 kwietnia $418 \mathrm{r}$. Synod biskupów afrykaúskich rozpoczą się niemal natychulast, bo już 1 maja: wśród 214 ojcóv obecny był oczywiście takze ów. Augustyn ${ }^{40}$. Pismo t ego synodu, skierowane do Zozyma, obstawało przy stwierdzeniu, że ekskomunika Innocentego I, dotycząca pelagian, pozostaje w mocy. Encyklika papieska pod nazwą "Tractoria", która dotarła do Afryki we wrześniu 418 r., oznaczała pełne poparcie Stolicy Apostolskiej dla doktryny o łasce i oczywiście osobiste zwycięstwo św. Augustyna ${ }^{41}$.

Papież Zozym po pewnej zwłoce przyjŁz zatem w całej rozciagłości stanowisko episkopatu afrykańskiego i swojego poprzednika na tronic Plotrowy. Mogło się rodzić pytanie, czy tamten rok wahania $i$ zwłoki nie oznaczał jakiegoś zachisania się wiary rzymskiej w sercu św. Augustyna. Okazuje się, że on nie żywiz takich myśli. Niezmiennie na bieżąco wykazywał, że papież Zozym nie odstapił nigdy od nauki głoszonej przez Innocentego I. Jego pobłażliwość wob́ec obu przywódców pelagianizmu dotyczyła 1ch jako ludzi, którym należało dać szansę, lecz nie obejmowała wiczym

40 Focjusz podał listę 225 ojcór tego synodu. Por. Bibliotheca 53, PG 103, 92, tłum. 0. Jurewicz/Focjusz, Biblioteka, Iarszawa $1986 \%$ t. $1, .35$.

41 Prosper z Akwitanii, czyniąc aluzje do synodów afrykańskich i decydującej roli św. Augustyna w dziele odrzucenta pelaglanizuu, tak whrótce napisał:

"Convenere Tui de cunctis urbibus almi

Pontifices, geminoque senum celeberrima coetu

Decernis, quod lloma probet, quod regna sequantur /.../

/... / An alium in finem posset procedere sanctum

Concilium, cui dux Aurelius, ingeniumque

Augustinus erat?" /Carmen de ingratis 76-92, PL 51, 100-102/. Por. Possidius, Vita S. Augustini 18, PL $32,48$. 
głoszonej przez nich nauki ${ }^{42}$. Można było zwieść biskupów Palestyny, ale wiary rzymskiej, chwalonej ustami Apostoła Pawła, nie udało się podejśćc 43 .

42 Por. Contra duas epistolas Pelagianorum II 3, 5, PL 44, 573575: "Imo vero Pelagiani spe falsa putaverant, novura et exsecrabile dogma polagianun vel Caelestianum persuaderi quorumdam Romanoruii catholicis mentibus posse; quando illa ingenia, qualivis nefando errore perversa, non tamen contemptibilia, cuin studiose corrigenda potius, quam facile damnanda viderentur, aliquanto lenius, quam severior postulabat Ecclesiae disciplina, tractata sunt. Tot entm et tantis inter Apostolican Sedem et Afros episcopos currentibus et recurrentibus scriptis ecclesiasticis, etiam gestis de hac causa apud illam Sedem Caelestio praesente et respondente confectis; quaenam tandem epistola venerandae memoriae Papae Zosimi, quae interlocutio reperitur, ubi praeceperit credi oportere, sine ullo vitio peccati originalis hominem nasci? Nusquam prorsus hoc dixit, nusquam omnino conscripsit. Sed cuin hoc Caelestius in suo libello posuisset, inter illa duntaxat de quibus se adhuc dubitare et instrui velle confessus est, in homine acerrimi ingenii, qui profecto si corrigeretur plurimis profuisset, voluntas emendationis, non falsitas dogmatis approbata est./... Sed si, quod absit, ita tunc puisset de Caelestio vel Pelagio in Romana Ecclesia iudicatum, ut illa eorum doginata, quae in ipsis et cum ipsis Papa Innocentius damnaverat, approbanda et tenenda pronuntiarentur, ex hoc potius esset praevaricationis nota Romanis clericis inurenda. Nunc vero cum primitus beatissimi Papae Innocentii litterae episcoporum litteris respondentis Afrorun, pariter hunc errorem, quam conantur isti persuadere, damnaverint: successor quoque eius sanctus Papa Zosimus hoc tenendum esse, quod ist1 de parvulis sentiunt, nunquan dixerit, nunquan scripserit; insuper etiam Caelestium se purgare molienten ad consentiendum supra dictis Sedis Apostolicae litteris crebra Interlocutione constrinxerit; profecto quidquid interea lenius actun est cum Caelestio, servata dumtaxat antiquissimae et robustissimae fidei firmitate, correctionis fuit clementissima suasio, non approbatio exitiosissima pravitatis. Et quod ab eodem sacerdote postea Caelestius et Pelagius repetita auctoritate damnati sunt, paululum iniermissae, iam necessario proferendae ratio soveritatis fuit, non praevaricatio prius cognitae vel nova cognitio veritatis"; Do gratia Christi II 6, 7; 7, 8, CSEL 42, 170-171.

43 Por. De gratia Christi II 8, 9, CSEL 42, 171-172: "Unde etiam Pelasius, si se ipsum et sua scripta sine dolo cogitat, non recte dicit, eaden sententia se non debuisse teneri. Fefellit enin iudicium Palaestinum; propterea ibi videtur esse purgatus: Romanam vero Ecclesian, ubi eum esse notissimum scitis, fallere usquequaque non potuit; quamvis et hoc fuerit utcumque conatus: sed, ut dixi, minime valuit. liecoluit enim beatissimus papa Zosimus, quid imitandus praecessor eius de ipsis senserit gestis. Attendit etiam quid de 1110 sentiret praedicanda in Domino Romanorum $\mathrm{fides} / \mathrm{hom} 1$, 8/, quorun adversus eius erroren pro veritate catholica, 
Cały ten spór miał w odniesieniu do św. Augustyna swój skromny, ale wiele znaczacy aneks. Oto w 418 r. biskup Hippony, który - jak wiemy - nie lubił podróży, a miał przy tym prawie 65 lat ${ }^{44}$, udał sie jednak do bardzo odległej Cezarei Mauretańskiej. Wracał później w pismach do tej sprawy, ale nigdy nie podał dokładniej przedmiotu swej misji. Stwierdzał tylko po prostu, że podjął tę podróż na zlecenie papieża Zozyma ${ }^{45}$. Wyglądało to tak, jakby obaj ci mężowie kościelni pragnnęli zaznaczyć, że można się spierać o metody działania, lecz papież pozostaje przełoźonym dla wszystkich dzieci Kościoła 1 zawsze należy go wspierać. Pobrzmierało tu poza tym echo sławnego sporu sprzed 160 lat, prowadzonego przez papieża Stefana i biskupa Cypriana, na temat ważności chrztu udzielanego poza oficjal nyn Kościołem. Teraz także biskup afrykaríski nade wszystko szukał koścịelnej jednosci

z Rzymem papieskim 1 umiał ją manifestorać światu.

W sprawie pelagianizmu św. Augustyn był wontakcie z pracownikami Kurii rzymskiej. Zatroszczył sie zwłaszcza o archidiakona Sykstusa 1 cieszył sie z otrzymanej odeń korespondencji. Biskup Hippony chwalił sykstusa za jego ortodoksje 1 zachęcał do działania dla dobra sprawy katolickiej ${ }^{46}$. Pragnąz mu szerzej wyjaśnić sprawy związane z doktryną pelagiańska $i$ umocnić go

studia consonantia concorditer plagrare cernebat: inter quos 1lle diu vixerat, et quos eius dogmata latere non poterant; qui Caelestium eius esse discipulum sic noverant, ut fidelissimum et firinissinum possent de hac re testimonium perbibere. Quid ergo de Palaestinae synodi gestis, quibus se Pelagius absolutum esse gloriatur, sanctus papa Innocentius iudicarit, quanvis ot in litteris eius, quas nobis rescripsit, legere possitis, et commemoratua cum venerabili papae Zosimo synodus Africana respondit, qued vestrae caritati cum caeteris instructionibus misimus, taisen nec in hoc opere praetereundum videtur". Nie udało sie té̀ później Julianowi z Eklanum, zwolennilowi pelagianizmu, wbić klina miz̧dzy stoliç Apostolską $i$ św. Aurustyla przez wysuwanie osliarizeń o jego manicheizmie i afrykaiskial nacjonal izaie /jor. Contra Iulianum III 17, 31, PL $44,718 /$.

44 IV nasiepnym roku mial juc po raz ostatni nawiedzić Kartaginę /por. F. van der Neer, dz.cyt., t. 1, 363/.

45 Epistola 190, 1, CSEL 57, 138: "Iniuncta nobis a venerabili papa Zosimo, Apostolicae Scdis episcopo, ccclesiastica necessitas". Por. De doctrina christiana IV 24,53 , CCL 32 , 159; Retractationes II 77, 51, PL 32, 610; Possidius, Vita S. Aurgustini 14, PL 32, 45.

46 Epistola 191, 2, CSLL 57, 164-165: "Nec illi negligens. sunt, 
w poglądach na łaskę. Jakby przeczuivając, że pisze do przyszłego papieża, nie przeoczył i tej okazji, by delikatnie wyrazić swój sąd na szczególną rolę nzymu w chrześcijańskim świecie ${ }^{47}$.

Sprara pelagianizmu miała się jeszcze ciągnąc wiele lat. Następca Zozyma na Stolicy Apostolskiej, Bonifacy I, stał na stanowisku doktrynalnym swych poprzedników 1 raczej nie podejmował od nowa tego tematu ${ }^{48}$. Pozwolił działać niechętnemu pelagianom czynnikowi państwowemu, a episkojat afrykański już sam zadbał o to, by władze w Rawennie nie traciły zapału w tej mierze 1 były właściwie ustawiane pod każdym względem. W sumie jednak pelagianizm różnych oduian aż o 100 lat przeżyz św. Augustyna. On sam do końca życia współpracował w jego zwalczanlu ze Stolica Apostolska. Nieugięty w sprawach pelagianizmu papież Celestyn I niemal na sama wiadomość o zgonie św. Augustyna napisał tak: "Był on w swoim czasie mężem tak wielkiej nauki, że również przez moich poprzedników był zawsze uważany za jednego z najle-

qui usque ad profundum silentium supprimunt timore quod sentiunt, sed tamen eamden perversitatem sentire non desinunt. Nonnulii quippe eorum, antequam ipsa pestilentia manifestissimo etiam Sedis Apostolicae iudicio damnaretur, vobis innotescere potuerunt, quos nunc repente reticuisse perspicitis; nec utrum sanati sint, sciri potest, nisi cum non solum dogmata illa Palsa tacuerint, verum etiam 1llis vera contraria eo, quo illa solent, studio defensaverint; qui tamen lenius profecto sunt tractandi. Quid enim eos terreri opus est, quos satis territos ipsa taciturnitas monstrat?"

47 Epistola 194, 7 /Ad Sixtum/, CSEL 57, 181, tłum. W. Eborowicz, POK 27, 57-58: "Tej to łaski zacięty wrogami sa pelagianie. Wprawdzie na rozprawie przed sąden kościelnym w Palestynie Pelagiusz, chcąc uniknąć skazującego wyrolsu, polęplł zwolenników porglądu, że Bóg daje łaskę zgodnie z naszymi zasługami; jednaik w ostatnich pismach pelagiańskich powraca teza o udzieleniu łaski za zasługi. Przede wszystkin w Liście do lizyrian Apostol przepowiada łaske. Chce, by ze stolicy śriata nauka jego szerzyla sie na caly świat".

48 Stojący nad grobein św. Hieronim nie byt rad $z$ takiej łagodności paf,ieza Bonifacezo /por. Hieronymus, Epistola 154, 1, CSEL 56, 367\%. 
pszych mistrzów" 49 .

\section{SPRAVA BISKUPA ANTONIEGO Z FUSSALI}

Spory wokół pelagianizmu nie tylko nie osłabiły, lecz raczej pogrłębiły w myśli św. Augustyna świadomość niezastąpionej roli Stolicy Apostolskiej w Kościele powszechnym i potrzeby zwi zzzków Kościołów lokalnych z papieskim Rzynew. Papieże czcill Biskupa Hippony, on zaś cieszył się podobnie wielkim uznaniem na cesarskim dworze i Ravennie. Ten właśnie dwór przypomniał sobie o Biskupie Ilippony, kiedy przyszło rozstrzygac wewnętrzne sprawy organizacyjne Stolicy Apostolskiej, wynikłe po śmierci papieża Zozyma.

Papiez ten zmarł 26 gruania 418 r. Szybko zabrano się do wyborów nowego biskupa lzymu, ale nie osiagnieto zgody. Jedno stronnictwo opowiedziało się za kapłaneri Bontlacym, podczas gdy drugie wybrało archidiakona Eulaliusza. Ten ostatni pospiesznie zajął katedrę papieską na Lateranie, a Bonifacy - początkowo niechętny swej kandydaturze - osiadł przy bazylice św. Piotra na Watykanie. Mediacje nie dawały rezultatu, a czas płynął.

Po kilku miesiacach negocjacji cesarz Honoriusz zarząził wielki synod kościelny w dniu 13 czerwca 419 r. w sprawie obsady Stolicy Apostolskiej. Poproszono na ten synod takze przedstawicieli Afryki łaciúskiej w osobach m.in. prymasa Aureliusza 1 śr. Augustyna.

Sw. Augustyn nie opuścił jodnak Afryki. W międzyczasie bowiem sprawa Eulaliusza została skompromitowana i cesarz uznał legalność elércji Bonifacego. Synod był zatem niepotrzebny. Sw. Augustyn nie ruszył do Italii, wiec też nie doszło do osobistego kontaktu Biskupa IIippony $z$ papieżem Bonifacym 1 jego kurlalnymi współpracownikami w nzymie.

Przed tym właśnie papiezem znalazła się sprawa dla św. Augustyna nienal osobistil. I:zecz dotyczyla człowieka, którego

49 Caelestius, Lipistola 21, 2, 3, PL 50, 530, tłum. A. Bober, AP 279; zob. wyzej s. 47.

49a Collect1o Avellana: Epistolae Honoril, CSEL 35/1, 60-88. 
Biskup Hippony od dziecka wychował, a następnie przedstawiz nieszczęśliwie do kościelnej promocji. Chodziło o biskupa Antoniego z Fussali.

Miejscowość powyższa znajdowała się na diecezjalnym terytorium IIippony $w$ odległośc1 ok. $60 \mathrm{~km}$ od kościoła biskupiego. Z wielkim truden 1 za cenę dużych poświęceń mieszkańcy Fussali zostali przez św. Augustyna pozyskani z donatyzmu dla jedności katoličiejjo. sówili oni językiem punickin. Św. Augustynzdecydował się utworzyć tân sanodzielną placówkę duszpasterska. Spośród własnych kapłanów upatrzył więc sobie kandydata i poprosiz prymasa Numidil, by przybył na miejsce i według zasad kościelnych dokonał śrięceń biskupich. Prymas przybył, ale kandydat cofnał swa zgode w ostatnim momencie. Sw. Augustyn stracił jakby panoranie nad zalstniała sytuacją. Dla ratorania twarzy wobec sęuziwego pryinasa zaproponował do sairry lektora Antoniego, który wyrósł w domu biskupim w Hipponie 1 tam pełnił swe funkcje, a narle wszystko - znał język punicki. Fussala otrzymała zatem biskupa.

Była to nominacja z gruntu nieudana. Młody biskup okazał się łakomy na dobra materialne 1 łatwo zrażał sobie ludzi. Synod biskupi w IItpponie polecił mu zwrot zagarniętych dóbr 1 zawiesił go w pełnieniu obowiązków, powstrzymując sie z innymi karami ze względu na jego miody wiek 51 .

Biskup Antoni poczuł sie skrzywdzony, ale działał z zachowaniem pozorów legalności. Omotał starego prymasa numidii

50 Por. Epistola 209, 2, CSEL 57, 348: "Actum est in Dei misericordia, ut omia ipsa loca unitati Ecclesiae cohaererent; per quantos labores et pericula nostra, longum est explicare, ita ut ibi presbyteri, qui eis congregandis a nobis primitus constituti sunt, exspoliarentur, caederentur, debilitarentur, excaecarentur, occiderentur. Quorum tanen passiones inutiles ac steriles non fuerunt unitatis illic securitate perfecta".

51 Tamże 209, 5, CSEL 57, 349-350: "Honorem itaque integrum servavinus iuveni corrigento, sed corrlpiendo minuinus potestatem, ne scilicet eis praeesset ulierius, cum quibus sic egerat, ut dolore iusto eum sibi praeesse ferre omnino non possent et cum suo llifusque periculo in alifuod scelus forsitan erupturam impatientian sui doloris ostenderent". 
1 otrzymał odeń list polecający do Rzymu. Papież Bonifacy przyjął apelację Antoniego, chociaż - trzeba to przyznać od razu czynił to z zastrzeżeniami ${ }^{52}$. Tak czy inaczej nakazaz przywrócie Antoniemu dotychczasowe stanowisko. Wolno mu byzo nawet odwołać się do ranienta świeckiego, gdyby społeczność kościelna Fussali nie chciala go przyjać. Papiez jakby nie dostrzegar faktu, że za całą sprawaz stoi przeciéz osobiście św. Augustyn 1 jego nalezalo koniecznie zapytać.

Papież Bontfacy zmarł 4 września 422 r. Jego następcą został Cclestyn I. Do niego więc zwrócił się listownie św. Augustyn, który był przejęty do żyego własnym błęden 1 zatrwożony bleglem wypadków. Stary Biskup Hippony namiętnie 1 zarliwie prosił nowego papieza, by biednym ludziom z IIppony Stolica Apostolska nie narzucała takiego porządku kościelnego, który jest gorszy od ich dawnego trwania w donatyzmie 53 . Oświadczał té papieżowi, że go gnębia wyrzuty sumienia 1 ma zamiar zrezygnować ze stanowiska biskupiego oraz poddać się pokucieza tak wielki błąd 54 .

Dalszy bieg wypadków nie jest nam znany. Tok innych wydarzeń pozwala przypuszczać, że papieź Celostyn od razu dał sie w tym punkcie przekonać i biskup Antoni już nie podjął duszpasterstwa w Fussali.

\section{SPRAVA KAPLANA APIARIUSZA}

Problem dyscyplinarny biskupa Antoniego z Fussali ukazał ubocznie cała złożoność apelacji afrykańskich do Kurii Rzymskiej.

52 W piśmie do papicza Celestyna św. Augustyn przypomnial następujące słowa Bontiacego w tej sprawie: "Si ordinein rerum nobis fideliter indicavit"/Epistola 209, 9, CSEL 57, 351/.

53 Tanze, CSßL 57, 351-352: "Iudicia quippe illis et publicas potestates et militares impetus tanquam exsecutaros Apostolicae Sedis sententiam sive ipse sive rumores creberrimi comminantur, ut miseri honines christiani catholici graviora formident a catholico eisiscopo, quam, cum essent haeretici, a catholicorum imperatorum legibus formidabant. Non sinas is ta fieri, obsecro te per Christi sanguinell, per apostoll Petri memoriam, qui christianorum pracpositos populorum monuit, ne violenter dominentur in Pralres".

54 Por. tauże 209, 10, CSiL 57, 352-353. 
Jeszcze wiqcej zamieszania wymołała apelacja kał łana Apiariusza, która absorbowała trzech kolejnych papieży, postawiła na nogi cazy episkopat afrykański i wystawiła na wielka próbę lojalność Kościoła afrykańskiego wobec Stolicy Apostolskiej.

Apiariusz pracowat w miejscowości Sicca Veneria u boku biskupa Urbana, wychowanka św. Augustyna. Urban odsunąz Apiariusza od Komunii za złe prowadzenie $i$ za czynione mu przykrości. Kapłan Apiariusz pominał wszystkie instancje afrykańskie 1 latem 418 r. udał się z apelacją do papieża Zozyma ${ }^{55}$. Papiez ten, który wyrzucał Afrykanom pośpiech osazdzeniu pelagian, sam zadziałał teraz z dziwnym pośpiechem. Przyjaz skargi Apiariusza 1 odesłał go do domu w towarzystwie legacji złożonej z biskupa 12 kapłanów. Mieli oni uzyskać w Kartaginie rehabilitację dla Aplariusza, przywrócenie mu stanowiska 1 uḱaranie biskupa Urbana. Legaci wzięli ze soba taki zestaw kanonów Soboru Nicejskiego, jakim wtedy dysponowano w Rymie, $i$ na ich podstawie miel1 ugruntcrać $w$ Afryce znana tam od dawna zasade swobodnego odwoływania się do Stolicy Apostolskiej.

Dla rozeznania sprawy zebrał się synod biskupóv afrykańskich. Wszystko odbywało się w atmosferze dużej nerwowości. Kiedy legaci papiescy powołali się w kwestii apelacji na Sobór Nicejski, Afrykanịe odpowiedzieli, że takich kanonów w Nicei nie ogłoszono. Zgodzili się jednak stosować do zarzq̨dzeń papieskich, aź prawda o tych kanonach zostanie ustalona.

Śmieré papieża Zozyma 1 niepokoje w Rzymie na początku 419 r. odsunęły zadraźnienie nioco w czasie. Legaci rzymscy pozostall w Afryce czekając na instrukcje od nowego papieza. W sprawie apelacji Rzyr miał oczywiście rację z każdej strony, także ze strony kanonów nicejskich - tyle że prawdziwych, a nie tych, które uparcie przywoływano, nie wiedząc, $1 \dot{z}$ uchwalono je nieco później w Sardyce 56 . Siprawa od początku była zatem trochę

55 Synody afrykańskie zakazywały niższemu duchowieństwu /z prezbiterami włącznie/ odwoływania sie od decyzji własnego biskupa do Stolicy Apostolskiej. Tak np. postanowił synod z $407 \mathrm{r}$. /por. Registri Licclesiae Carthaginensis excorpta 1051125 ; CCL $149,2181227 /$.

56 Prawo apelacji zawicra sie imjlicite w 6 kanonie Soboru Nicejskiego, gdzie jest mowa o zwierzchniej władzy llzytu, Aleksandrif i Antiochil /por. Concjliorum oecumenicorum decreta, dzecyt. $8 \mathrm{n} /$. 
źle ustariona, a urażeni Afrykanie uchwycili się tego niezawinionego błędu taktycznego i postanowili, przy okazji clochodzenia prawdy o uchwałach nicejskich, dochodzić także swych prawdziwych czy tylko domniemanych przywilejów $\$$ zakresie administracyjnej autonomil kościelnej.

Za pontyfikatu Bonifacego plenarny synod w Kartaginie podjął w maju 419 r. sprawę Apiariusza. Postanowiono przyjać go do normalnej pracy w Kościele, ale poza miejscowościa Sicca Veneria. Synod dalej żądał weryPikacji kanonów nicejskich. Posłano po ich teksty do Konstantynopola, Aleksandril 1 Antiochil. Na razie Afrykanie prosili Bontfacego, by za jego życia nie miazy miejsca pollobne incydenty ${ }^{57}$.

Sir. Augustyn brał udział we wszystkich tych zdarzoniach. On równiez opowiadał się za sprawdzeniem, có mówią autentyczne kanony nicejskie. W swoin umiłowaniu prawdy nie mógł się zgodzić, by dobra sprawa opierała sie na niepewnych fundamentach. o to papież nie mógł mieć do niego żalu.

I rzeczywiście. Ten spór na wielkim forum kościelnyın nio rpłynął w żaden sposób na stosunek Biskupa Hippony do papiestra $i$ do osoby urzędującego papieża, a Bonifacy odpłacał się wzajemnościa. Kiedy bowien w Rzymie zjawil sie biskup Tagasty i przyjaciel św. Augustyna, Alipiusz, papież przekazał przez niego dwa listy pelagiańskie na ręce św. Ausustyna, prosząc Biskupa Hippony o zredagowanie stosownej na nie odpowiedzi ${ }^{58}$. Wikrótce powstało dzieło, dedykowane właśnie papieżowi Bonifacemu. Znalazło sie w nim dużo akcentów wspierających ideę pryratu rzymskiego 59 . Szczególnie piękna i pouczająca była cała dedykacyjna przedmorra do tego dzieła.

Tymczasen Apiariusz, usunięty z Sicca Vencria, osiadł w nadmorsiciej Tabarce. Tam niebawem zasłużł sobie ponownie na

57 Por. Epistola concilii Carthaginensis ad Bonifacium papan 26 Blaif 419, CCL $149,159 \mathrm{n}$.

58 Por. lietractationes II 61, 1, PL 32, 655; P. Batiffol, Le catholicisme, dz.cyt., $451 \mathrm{nn}$.

59 Por. Contra duas epistolas Pelagianorum I 1, 1-2, PL 44, 550551: "Neque enim dedignaris, qui non al ta sapis, quanivis altius praesideas, esse anicus humiliuw /.../ Communisque sit omnibus nobis qui funrimur episcopatus officio/quamvis ipse in ea praeemineas celsiore fastigio/ specula pastoralis; facio quod possum pro mel particula muneris". 
ekskomunikę. K1edy na Stolicy Rzymskiej zasiadz Celestyn I, Aplariusz ruszyl starym szlakiem do nowego papieza. Stała sie znowu rzecz dziwna. Celestyn zaopatrzył Aplariusza w list uniewinniający 1 przydał nu do tovarzystwa swojego legata, znanego juz Afrykanom z wydarzeń 419 r., biskupa Faustyna.

Afrykański synod plenarny odbył sie ok. 426 roku 60 . Jego obrady przebiegały znowu w atmosferze napięcia. Przesłuchania Aplariusza 1 zeznania świadków trwały 3 dni. W ogniu pytá́ 1 ciągłych oskarźeń Apiariusz załamał się 1 przyznał w zupełnośc1 do zarzucanych mu występków. Legat papieski nie.znalazł argumentów na jego abrone 1 ustiapiz.

Powrócil teraz na wokandę problem apelacjl do Rzymu w oparciu o przedłozone przez legata kanony nicejskie, których teksty nadeszły ze Tschodu. Okazało się, że $\mid$ Rzymie - podobnie zresztą jak 1 Mediolanie, przynajmniej za czasów św. Ambrożego - dokonało sie niezanierzone pomieszanie uchwał nicejskich z kanonami przyjętymi 20 lat później w Sardyce ${ }^{61}$. Te ostatnie, mówiące wprost o apelacjach biskupów całego świata do biskupa rzymskiego, uważano po prostu za dalszy ciąg kanonów nicejskich.

W obu punktach - Aplariusza 1 apelacji - Afrykanie, jak sie Im wydawało; pokonali legatów papieskich. Do Rzymu starym zwyczajem poszły akta sprawy Apiariusza. Ale triumfujacy Afrykanie, jakby dla przeclwwagi, dołączyli do tych akt szczególny list do papieza Celestyna. Postulowano wim, aby Stolica Apostolska nio przyjmowała na przyszłość odwołań z Afryki 1 nie dopuszczała do jednosci kościelnej takich ludzi, którzy w Afryce zostali jej pozbawleni. Papiez został równiez pouczony, ze takie metody postepowania wprowadzaja do Kośc1oła "typhus saeculi". W sumie oznajmiono Fięc papiezowi, ze zabrania sie biskupom 1 całemu duchowieństwu afrykańskiemu apelacji do Rzymu 62 .

60 Niektórzy Jako pewnaz podają datę 424 /por. np. W. Marschall, $\mathrm{dz}_{\text {.cyt.1, }} 4 \mathrm{nn}, /$.

61 Por. T. G. Jalland, The Church and the Papacy, London 1944, $289 \mathrm{n}$.

62 Por. Epistola "Optaremus", CCL 149, 169-172. 
Narzuca s1e oczywiścle pytanie, jak sw. Augustyn mógł podpisać dokument, który jednym pociagnieciem pióra zrywał z odwieczna tradycją afrykańskiego apelowania do Rzymu, pośrednio godziz $w$ rzeczywiste kanony nicejskie 1 arbitralnie regulował prerogatywy nastepcy śr. Piotra. Została przeciez, przynajmnief intencjonalnie, zakwestionowana suwerenna władza biskupa rzymslriego nad porvazną częścia Kościoła powszechnego - 1 to wodatku na łacińskim Zachodzie!

Rzecz w tym, ze wcale nle wiajomo, czy św. Augustyn w ogóle brał udziaz $w$ omawlanym synodzie. Powyzisy list do Celestyna I nie zawiera podpisu ani św. Augustyna, ani jego przyjaciela Alipiusza, podpisał go natomiast zasłużony, ale juz bardzo stary prymas Aureliusz 1 zaledwie 14 dalszych biskupow o blizej nieznanych imionach. Wygląda na to, że sw. Augustyn nie redagowal tego tekstu. Poza tym jest wprost pewne, ze na taki ton 1 na takie rozwiązania on rie dawał zgody, bo nie takie było jego pojęcie porządku w Kościele ${ }^{63}$.

Rozstrzy yające wydaje się tu dowodzenie E. Caspara, którego nie można posądzać o aprioryczne sympatie do papiestwa. Powołał sie on na list tego samego papieźa Celestyna do biskupów Gal11, napisany w maju $431 \mathrm{r}$., czyli praktycznie zaraz po śmlerci św. Augustyna. Oto ten papież, w którego jakby osob1ścle godziły pochopne uchwały synodu afrykańskiego sprzed kilku zaledwie lat, pisał o zmarłym Biskupie Hippony: "Ze świętej pamlęci Augustynem utrzynywaliśmy zawsze kączność dla jego zycia 1 zasług. I nawet cień niecnycí podejrzeń nie padz na niegon ${ }^{64}$.

W zaistniałej sytuacji papież wobec całego świata chrześcijańskiego dawał swiadectwo dla niezmiennej wierności św. Augustyna wobec Stolicy Apostolskiej. Celestyn czyniz to śriadomie 1 celowo 65 . Spłacał w ten sposób dług temu, który najwi-

63 Por. P. Batiffol, Le catholicisme, dz.cyt., $471 \mathrm{nn}$.; F. van der Neer, dz.cyt., t. 1, 425 /przypis 44/; M. Marschall, dz.cyt., 185 nn. Nal eźy zauważyć, że 15 biskupów - choćby razem z pryiascin Kartaginy - to nie episkopat afrykariski. lecz bardzo skromna jego cząstkal

64 Lisistola 21, 2, 3, PL 50, 530: "Augustinum sanctae recordationis virun pro vita sua atque meritis in nostra communione seliper habulmus, nec unquam hunc sinistrae suspitionis saltem rumor aspersit". Tekst oryginalny, $j$ ak to ividać $z$ porównania, jest w swej wymowie dużo mocniejszy niż nicco wyblakłe tłumaczenie polskie /A. Bober, AP $279 /$.

65 Por. E. Caspur, Geschichte des Papsttums, Bd. 1, Tubingen $1930,372 \mathrm{n}$. 
doczniej odłoży na bok wleloletnią przyjaźn z prymasem Aureliuszem, stanąz po stronie prawdy 1 mądrze broniz. Stollcy Apostolskiej jako fundamentu jedności Kościoła powszechnego.

$$
\text { Z a k o ń c z e n } 1 \text { e }
$$

Na podstawie przedstawionych laktów, które przy dzisiejszym stanie znajomości źródeł tylko w drobnych szczegózach mogá być niekompletne, moźna się pokusić o nieżbędne uogólnienia. Jakie były zatem główne katolickie rysy św. Augustyna, tego najwiekszego z Ojców Kośioła łacińskiego, a moze nawet najwybitniejszego ze wszystkich ojców? Jakie wnioski nasuwaja się po analizie jego wieloletnich kontaktów z Rzymem papieskim?

Wiadomo, ze św. Augustyn był człowiekiem wielkiego intelektu 1 równie wielkich uczuć. W mýsleniu był wierny faktom, szanował tradycję kościelna, a do naczel nych jego aksjomatów należało uznanio dla Instytucjl Kościoła 1 dla zasad porząku w społecznośc1 ludzkiej. Jako neofita, a następnie jako kapłan 1 biskup, coraz mocniej wrastał wościół. Był mężem o nigdy nle słabnącym myśleniu uniwersalnym - jak św. Ambrozy - ale tez był synem lokal nego Koścloła afrykańskiego, jak św. Cyprian. Te dwa wzory osoboile trzeba mieć na uwadze, gdy chce slę pojąc, co on myślał o papiestwie 1 jak swe przenyślenia wcielat $w$ czyn.

Sw. Augustyn wyraźnie uznawał doktrynalny autorytet Stolicy Apostolskiej. Nie doszedł wprawdzie do punktu, by expressis verbis określić wiarę wieomylność papieska, ale przeciez nie ina tez u niego sformułowań o nieomylnośc1, np. soborów powszechnych ${ }^{66}$. Ta problematyka nie jawiła mu się jeszcze zbyt ostro. Uwazaz natomiast za niezbędne reagorac solidarnie z Innymi biskupani przeciwko niektérym formom apelacji do Rzymu painleskiego 1 pewnyn sposobom interweniowania w Apryce, podejmovanyin przez Kuris Rzymskiz. Ale w rzoczywistości byt to mąz

66 Por. F. van der Meer, dz.cyt., t. 1, 40 n.; tarize, 424 /przypis $31 /$. 
o myśleniu rzymskokatolickim. Gdy więc tylko chodziło o causae maiores - Jak tego chciał Innocenty I - on indywidualnie lub razem z innymi odwoływał się do Stolicy Piotra67.

Sivięty Biskup Hippony był człowiekiem głębokich uczuc. Wizyty w Rzynie, z lat młodości 1 wewnętrznych przemian, musiały pozostawić w nim korzystne skojarzenia ${ }^{68}$. Rezultat wrośnięcia w katolicka tradycje Afryki, zachwytu św. Ambroźym 1 własnych przé̇yć z czasu młodości był zatem łatwy do odgadnięcia.

Sw. Augustyn ceniz 1 szanował papieski nzym. W kazdym niemal jego nawiązaniu do zwrotu "Stolica Apostolska", czy odniesieniu do osoby urzędującego biskupa Rzymu, zavierał sie ładunek przywiłzzania, a nawet miłości ${ }^{69}$. Było to przywiazzanie dyskretne, oszczędne w słowach 1 pozbawione patetycznych deklaracj1. Kiedy jednak augustyńskie spojrzenie. na papiestwo rozważa się na tle całokształtu jego tirórczości i waźniejszych szczegółów źycia, to obraz takiej całości jest bardzo czytelny. Stol1ca Apostolska w Rzymie miala w Biskupie Hippony inteligentnego 1 wiernegro szermierza katolickiej 1dei Piotrowej.

\section{Bp Jan Srutwa - Lublin}

\section{LES CONTACTS' DE SAINT AUGUSSTIN AVEC LA ROME PONTIFICALE Résumé}

Saint Augustin a demęuré à Rome deux fois, à savoj̣r au début et à la fin de son sejour en Italie, dans les annés 383388. Mais on ne sait rien sur ses contacts avec la Curie Romaine a cette époque-1à.

67 i sprawie bisł́cupa Auxiliusa, który na tle praktyki azylu koscielnego ekskomunikował komesa classicianusa, Augustyn pisał o konfeczności odwołania się do synodu afrykańskiego, albo "si opus fuerit, ad Sedem Apostolicam"/Epistola 250 A, CSEL 57, 598/.

68 Grób Plotrowy w Rzymie był w Jego oczach drozszy państwu rzymskiemu niż świątynia Romulusa: "Ostendatur mihi Romae in honore tanto templum Romuli, in quanto ibi ostendo memoriam Petri" /Enarrationes in psalmum 44, 23, CCL 38, 511/. Nawet cesarze modla sie tam u grobu rybaka z Galilei/por. Epistola 232,3, CSEL $57,513-514 \%$

69 Papiez jest dla niego gwarantem pokoju w Kościele 1 ojcem całego luciu chrześcijańskiego. Por. Eplstola 43, 16, CSEL 34, 98 /podsumowanie działalności papieża Milcjadesa/: "O v1rum optimunl o filium christianae pacis et patrem christianae plebis l" 
Quang 11 est devenu prêtre, et ensuite évêque, 11 ne quittalt pas, 1 afrique, alors il ne visitait non,plus Rome. Il est tres intéressant, d autant plus, de savoir $s^{\prime} 11$ y avait - pendant ces 40 ans - des contacts de Saint Augustin avec le Siege Apostolique et comment ils se présentaient.

Au début, Saint Augustin était pur la papauté un de nombreux évêquęs africains de cętte periode. Mais la crise pélagienne a tout change; elle a démontre la grandeur de l évêque d'Hippone en tant que penseur catholique et homme d'action dans l'Eglise. A la fin du pontificat d, Innocent $I$, on voit Saint Augustin parmi les plus importants de 1 épiscopat africain, tout près du primat Aurélius. L'evêgue d'Hippone savalt bien maintentr de bonnes relations avec le Siege Apostolique dans les moments difficiles et fréquents, causes par l affaire pélagienne et aussi par les complications liées avec les appels du clergé apricaln a Rome. Cette gituation a eu lieu sous les pontipicats de Zosime, Boniface et célestin. La tradition de 1 'Eglise a présenté défintivement les relations de Saint Augustin avec le Siege Apgstolique en forme d aphorisme: "Roma locuta - causa Pinita". "etait le pape Célestin I qui a rendu le plus beau hommage a l'attitude catholique de Saint Augustin juste apres sa mort. 